Rupantaran : A Multidisciplinary Journal

Vol. IV : pp 121-132, October, 2020

ISSN : 2091-0061

https://doi.org/10.3126/rupantaran.v4i1.34207

Research Management Cell (RMC)

Dhankuta Multiple Campus, Dhankuta

Tribhuvan University, Nepal

\title{
Use of ICT in Classroom: An Analysis of Teachers' and Students' Perception on ICT Tools
}

\author{
Nirmal Raj Mishra ${ }^{1}$ \\ Email:nirmaltu@gmail.com
}

\section{Abstract}

The ICT integrated teaching forcefully underpinning in our education system as a pedagogical intervention. The teachers and students are trying to habituate with incorporating their teaching learning activities. In this situation, this study has to explore the situation of ICT tools use by teachers and students for ICT integrated teaching in higher education classroom. For this purpose, I adopted the social constructivist approach of learning for supporting to view the reality. Based on this theoretical approach, I used the qualitative research design where applied the phenomenology method of inquiry. The three methods focus group discussion, in-depth interview and personal introspection have used to collect the in-depth information from the informants. The major finding is that the social media tools like Face book, Gmail, Blogs were not popular in teaching. The teachers and students are used the hardware related tools like laptop, desktop computer, multimedia projector, cell phone and software related tools like office program, Face book, twitter, blog. The highly prefer tools have laptop/desktop computer, multimedia projector, cell phone and software tools like internet, email, office program and related apps like Moodle. The ICT tools are inevitable phenomena for effective delivery of knowledge and skills in higher education teaching to meet the global needs of education.

Key Words: collaborative learning, ICT, hardware and software, social media

\section{Introduction}

There are increasing number of computer and other technology in our everyday life. Many students and teachers have using these technologies for better knowing and new way of learning. The ICT impacts every aspect of our life like teaching, learning, reporting, communicating and so on. Though, educational systems around

1. Mr. Mishra is a Lecturer of Curriculum and Evaluation at Dhankuta Multiple Campus, Dhankuta. 
the world are under increasing pressure to use the new information and communication technologies (ICTs) to teach students the knowledge and skills they need in the $21 \mathrm{st}$ century (UNESCO, 2002, p. 1). It is the most emerging phenomena for the school and college education. It has created the new discourse of pedagogical transformation in education (UNESCO, 2014).

The age of technology, everyone wants to do something in ICT tools (Aktaruzzaman, Shamim \& Clement, 2011). The educational institutions are also influenced with this technology and most of these have tried to adopt it. The teachers and students are not exception to use these tools. This tool helps to transform the teachers and students into the technocratic society (Mbangwana, 2008). Lam and Lawrence (2002) stated that the technology not only gives learners the opportunity to control students' own learning process, but also provides them with ready access to a vast amount of information over which the teacher has no control. Treagust and Rennie (1993) stated that the teachers can communicate locally and globally with others to gain confidence and competence through the communication and technology tools. They can use the internet networks to communicate and seek support from experts, search in different websites and resources about education. Similarly, Hennessy, Harrison \& Wamakote (2010) stated the role of the teacher is utterly critical.

The ICT is an umbrella term that includes the communication device or application, as, radio, television, cell phones, computer and network hardware and software, satellite systems and so on, as well as the various services and applications associated with them, such as videoconferencing and distance learning. ICT are often being spoken of in a particular context, such as, communication and technology in education, health care, or libraries (Tech Target, 2007, p.1). The ICT tools are more popular in student centered leaning and helps to transfer the teacher centered and textbook bounded classroom into the students centered and interactive teaching learning environment. Now days, it is essential to meet the global challenges in teaching learning in order to promote the self-paced learning (UNESCO, 2005).

ICT tools help to gain the confidence and competence of the students and teachers. Those, who use it, they can communicate to the local and global experts and collect the resource about education (Treagust \& Rennie, 1993). The technology determines the effectiveness of teaching and learning (Ryba, 1992). In present scenario, ICT plays the important role to increase the learner's motivation (Olteanu, Dumitrescu, Gorghiu \& Gorghiu, 2007). Similarly, Luu (2009) also stated the importance of ICT tools for the better achievement, those students, who have the prior experiences of ICT skills and browse the internet frequently and confident with basic ICT skills, they can earn higher scientific scores. Likewise, Rhema and Miliszewska (2014) claimed that 
the positive attitude towards ICT use is influenced by the access to technology and internet facilities. With the help of ICT as pedagogical tools, various teaching learning strategies can be applied in the classroom that facilitates the classroom activities (Ndibalema, 2014).

The rapid changes of society and way of people to communicate acquire and generate the knowledge; this demands new teaching learning paradigms (Mbangwana, 2008). In Nepal, it has trying to adopt this new teaching learning paradigm. The policy document like information technology policy (2010), school sector reform plan (20092015), ICT in education master plan (2013), national curriculum framework (2014) and school sector development plan (2016-2023) has provided the strategies to integrate the ICT in education. These documents fundamentally focused on the provision of expansion of internet access, development of ICT infrastructure, cooperation with national and international institutions to develop skilled human resources and implementation it's in teaching as well learning (Ministry of education [MOE], 2013).

The discussion cleared that the pressure of ICT intervention is inevitable in higher education classroom to meet the societal needs and transformation of society in Nepal. At now, the higher education institutions are trying to establish the ICT as an instructional tool for learning. Due to this scenario, this study has explored the condition of using ICT in teaching and learning. For this purpose, this study has solved the research questions such as a). what are the ICT tools use in the classroom? and $b$ ). what are the ICT tools that teacher and students prefer for learning?

\section{Methods and Materials}

The underlying philosophy or worldview of this study has postmodern where adopted the social constructivist approach to search the realities. Based on this philosophical standpoint, the ontology has multiple realities which grasped through the analysis and interpretation of informants' feeling and perceptions. Similarly, the experiences of teachers and students are the source of knowing that has embraced as epistemology. Through this ground, I have chosen the qualitative research design as a methodology. The qualitative research involves to searching the peoples feeling, ideas, perceptions, and thinking. In qualitative research, the nature of information is very subjective and does not believe on the number value of information (Guba \& Lincoln, 2005). Within the qualitative research, I selected the phenomenology as a research design. Phenomenological study describes the meaning of several individuals of their lived experiences of a concept or phenomena (Creswell, 2007, p. 57). It is not only a description, but it is also seen as an interpretive process in which the researcher makes an interpretation (p. 59). I have considered the ICT as phenomena where teachers and students' perceptions and feelings were collected for intensive findings. 
The whole research has used the primary sources of information relating with verbal texts and feelings towards the ICT tools. The primary sources provide the first hand and original information from the research participants and fields (Best and Khan, 2006). The Tribhuvan university, Sanothimi Campus, Bhaktapur, Nepal has selected as a research field. The research field were selected as per the convenience of researcher where applied the convenience sampling strategies. I selected the ten teachers and sixteen students through the purposive sampling for collecting perceptions on ICT tools in classroom.

I have applied the in-depth interview, focus group discussion and researcher introspection methods to collect the information from teachers and students. The data collection methods have helped to analyze the teachers and students' perceptions on ICT tools used in the classroom. After collecting the information, I developed themes (Creswell, 2007, p. 46) out of the narratives and organized them in a reductionist's way (Wiersma \& Jurs, 2009). The reflective notes were used for theme generation and used interpretive way of analysis.

\section{Results and Discussions \\ Use of ICT in the classroom}

I found that most of the informants were aware on the use of ICT in teaching. They adopted the ICT tools like cell phone, laptop, computer, internet services at home and classroom. Along with this; they have access to desktop computer, laptop, smart phone and internet. Especially, they focused on the ICT tools for self-tutoring and communication. Sometimes, they used the computer and printer for the distribution of hands out. But the problem is that the teachers used the aforesaid tools for self-learning; they have not used them in teaching. Similarly, they used multimedia projector to show the audio-visual materials occasionally. They also used email, Google search engine and office program like Word, Excel and PowerPoint for material preparation and distribution. Computer teachers, others young and new admitted teachers had better skills in technology use. The cell phone was the common tools for reading pdf and word file. Likewise, they have used multimedia projector for material demonstration. In other side, the students used it for seminar and thesis presentation only.

In the beginning, when these tools helped them to disseminate the information among the friends, they were curious to learn other software and tools like drive, twitter, and blogs. After that, they realized the importance of ICT tools. Now, they felt that it was supportive for their learning and also support for the demonstration of their lesson. To support this idea one teacher said; "For audio documents, I usually use cell phones, for short clips for listening or visual, I might use lap top, for detailed and lengthy type of documents, I use multimedia in my classroom...." 
Likewise, another succession experience expressed by teacher is that;

"I mostly used Power Point presentation to present my lessons. Similarly, I also use Google to search materials and present. In the same way, I explore internet to find out sample materials for reading and sample researches to make my students be familiar with current international trends in research.'

The male and female both teachers were found using the laptop/computer, internet explorers, and power point presentation. They used it for the documentation, materials demonstrations and entertainment. They also used the social media like Facebook, Skype and Gmail for communication. The one male teacher used twitter and he shared the social and political issues in short jargons. The male teacher used the cell phone for materials demonstration and storage. But in contrary, the female teachers usually engaged in the Google search through the computer/laptop. All female teachers had android cell phone but not used for the storage of reading and listening materials. They also used the internet through the laptop. In contrary, the male teachers frequently used the internet through cell phone. They used laptop for the purpose of type and storage the materials.

In some cases, the viewpoints of students were varied from teachers. They said that they used Skype, viber, and remote controller software for communication. They also used laptop without internet and with internet. They used the computer/laptop and printer to prepare seminar paper, assignment, practical reports and thesis. Varied experiences were found between three to five years in ICT tools. Recent practice of video conferencing has been proved as a supportive tool of teaching learning. In video conferencing, they felt it helps to learn and exchange the ideas with friends in live mode. Sometimes they get chance to learn and share with their and learn from them.

The student used laptop for type materials and stored the documents like report, and others Word and pdf file, video etc. The laptop/computer also supported them to prepare the assignment paper, project work, essay writing. Similarly, they presented these tasks through the multimedia projector. They frequently used the power point slide in paper presentation through the use of laptop, iPod. Additionally, they used the cell phones for demonstrating audio/audio-visual materials. One student supported the fact that in this way; "cell phones are very useful for short clips of listening or visual". It can be claimed that the students were interested to learn thorough the audio visual materials. They used them as most common ICT tools for their learning. Cell phones were most popular tools for them to search the complex word meaning in dictionary. It had helped them to be updated. Moreover, they used the internet in cell phone frequently. When they need to learn and get answer instantly, they used mobile data and Wi-Fi. 
Both boys' and girls' students used laptop, and cell phone. They used internet through the cell phone and laptop. They both used it for use of Facebook, Gmail, Skype and viber. The one boy student used the cell phone to prepare the ppt slide and other papers. He frequently used in the classroom. He used the Google search during the class teaching. The semester students used laptop to prepare the assignment and project paper. They used it because it is necessary to prepare the paper. In contrary, the annual students used it for the messaging, communication and entertainment.

The discussion above helps understand that teachers and students were very curious to use the ICT tools in their learning. They adopted the various types of tools and used it differently. The theme of the discussion above has been presented in the following table.

Table 1: ICT tools used by teachers and students

\begin{tabular}{|c|c|c|}
\hline Informants & ICT tools & Used area \\
\hline $\begin{array}{l}\text { Used by } \\
\text { teachers }\end{array}$ & $\begin{array}{l}\text { Mobile, laptop/computer, } \\
\text { internet, multimedia } \\
\text { projector, cell phone etc. }\end{array}$ & $\begin{array}{l}\text { Classroom teaching, documents presentation, } \\
\text { seminar presentation, thesis presentation, } \\
\text { materials development and delivery }\end{array}$ \\
\hline $\begin{array}{l}\text { Used by } \\
\text { students }\end{array}$ & $\begin{array}{l}\text { Internet, } \\
\text { computer/laptop, } \\
\text { multimedia projector, } \\
\text { Gmail, yahoo. Facebook } \\
\text { etc. }\end{array}$ & $\begin{array}{l}\text { Thesis presentation, seminar paper } \\
\text { presentation, thesis typing, materials } \\
\text { exchange, demonstration of specific contents } \\
\text { and questions answer of the content related } \\
\text { problems }\end{array}$ \\
\hline $\begin{array}{l}\text { My } \\
\text { reflection }\end{array}$ & $\begin{array}{l}\text { Frequently used tools: } \\
\text { cell phone and Facebook } \\
\text { Occasionally used } \\
\text { tools: internet, laptop, } \\
\text { multimedia projector } \\
\text { and others internet } \\
\text { and Microsoft related } \\
\text { programs like word, } \\
\text { excel, PowerPoint } \\
\text { and Facebook, Gmail, } \\
\text { Google search. }\end{array}$ & $\begin{array}{l}\text { Cell phones and Facebook for contacted } \\
\text { their friends, teachers and students used to } \\
\text { store the reading, audio and video materials. } \\
\text { Used for the mandatory purpose in their } \\
\text { learning like thesis and seminar presentation, } \\
\text { materials delivery. } \\
\text { Teachers were frequently used it for the } \\
\text { reading like book, newspaper and research } \\
\text { article and report through the mobile data } \\
\text { and other networks. } \\
\text { Teachers used to search the materials and } \\
\text { delivery materials to the students and friends. } \\
\text { Others tools like word and PowerPoint were } \\
\text { used for the note making. The multimedia } \\
\text { projector used for the PowerPoint } \\
\text { presentation. }\end{array}$ \\
\hline
\end{tabular}


The social media tools such as Facebook, twitter were not popular among the teachers to promote the learning. These tools were not commonly used for instruction but they were only used for the entertainment purpose. Most of the teachers and students whom I consulted had accessed in ICT tools and they used it for their personal purposes like communication, entertainment, and materials storage. The students had little accessed in ICT tools viz. Internet and computer in campus. But all of them had cell phone. They adopted the facilities through cell phone. The reason was that campus had limited internet facilities and could not provide for all teachers and students. Only a few teachers and students were found directly and indirectly involved in the ICT program. The limited computer and multimedia projector facilities are found at the campus. The students with computer course and their teachers had internet and other lab facilities. But the other teachers and students had no sufficient access to them.

Based on this result, I found that the teachers used the hardware related tools like laptop, desktop computer, multimedia projector, cell phone and software related tools like office program, Facebook, twitter, blogs. They used it for the self-tutoring and communication. They also used the tools for dissemination of hands out and reports. The younger teachers were found more energetic than elderly teachers. They used mobile for file reading and multimedia projector for materials demonstration, and seminar presentation. Moreover, I also found that the students used more advanced tools for the communication and entertainment. They had also used similar tools that teachers used. They used tools like Skype, Viber and the cell phones as the most common tools for the dissemination of information.

\section{Preferred tools for learning}

In this study, I found that the teachers preferred the mobile/cell phone as the convenient tools for learning. Internet was also used adequately with the help of mobile data. For the documents presentation, the tools like Microsoft word, excel, Power Point, could be used for presentation and report writing. They emphasized on the concept of e-library. They both male and female teachers preferred the tools like laptop, internet, and multimedia projector. The male and female teachers also said that the interactive whiteboard, e-books/library will facilitate to the students for rich and intensive information. In contrary, the female teachers preferred the tools like power point slide, YouTube, google search but male teachers preferred tools like email, Moodle, and blog. They both argued that such types of tools were used in developed countries and we could also use it in low cost. Moodle for them would help the materials delivery, assignment checking, quiz, report submission etc. in the synchronous and asynchronous ways. 
In all both the male and female teachers preferred the mobiles, laptops, projectors, various blogs and websites could be used in higher education. These tools for them were more applicable in our context because these were easily available in our colleges and daily life. According to them it could be used to promote the collaborative and projective versus lecture method. These tools for them were valuable for teachinglearning because the teachers try to incorporate it. The students also become familiar with and it made learning easier and permanent. It mostly helped the visual learners also.

Students preferred the multimedia/multimedia projector as the effective tool for showing the images, video, sound, text, slide and cassette recorder etc. in the classroom. For them these tools were effective because it created the more euthenics and funny teaching learning environment. They also preferred the interactive whiteboard because it helped the teachers to structure their lessons. They believed that it could also develop the cognitive skills of the students and promote the collaborative learning. For the collaborative learning environment, they preferred the movable or flexible setting arrangement where the desk and chair would move on the bases of their need. They also argued that it was necessary to conduct the project based learning. They believed that it would develop the students' ICT skills and teachers' confidentiality.

The students highly focused on internet for updating the information. The science, English, math and computer students preferred the internet, computer, laptop, multimedia projector, Google search etc. They also argued that the campuses had not managed these tools and reluctant to provide to them. Some of the teachers used it for their easiness only. As a result, the classrooms did not become more interesting. In their view, there were several facilities but not convenient for all. Apart from the students studying computer course, other students they had no idea about the whiteboard, webinar, Moodle and others interactive tools. They put the value of ICT tools for their improvement of learning. They highly valued on the English language for digital literacy. They told that without the English literacy, it was difficult to search, manage and read the information. It was also found difficult for them to use and select the appropriate tools. It showed that students preferred the English literacy for digital skills.

Now a day, people have become habitual with the ICT and they have adopted technology in their lives. They believed that ICT tools were valuable and helpful to make effective teaching learning process easily. One informant supported this view by saying; "Nowadays people have become ICT addict and they have technological their lives with ICT, they are certainly valuable." The reasons behind these enabled personalized learning, enhanced teamwork and cooperation, improved academic 
reporting, sound educational investment, increased global competition, increased global collaboration.

As I found the teachers preferred the tools for supporting their lectures and demonstration and students preferred for the documents distribution, documentation, inquiry and information collection. They preferred the ICT tools for the effective teaching and learning and put the values it differently. The preferred tools and their values have been presented the following table.

Table 2: Preferred tools and their values

\begin{tabular}{|c|c|c|}
\hline Preferred by & Tools & Values \\
\hline $\begin{array}{l}\text { Preferred by } \\
\text { teachers }\end{array}$ & $\begin{array}{l}\text { Hardware tools: } \\
\text { laptop/computer, multimedia } \\
\text { projector, mobile phone, } \\
\text { Software tools: internet, } \\
\text { email, Microsoft word, excels, } \\
\text { PowerPoint, Moodle. } \\
\text { Convenient tools: mobile } \\
\text { phone }\end{array}$ & $\begin{array}{l}\text { Supporting their lecturer and } \\
\text { demonstration of materials. } \\
\text { Showing the photos, video } \\
\text { materials through it. } \\
\text { Investigate new things and help } \\
\text { to compete in global market. } \\
\text { Help to increase the global } \\
\text { competition. }\end{array}$ \\
\hline $\begin{array}{l}\text { Preferred } \\
\text { students }\end{array}$ & $\begin{array}{l}\text { Hardware related: internet, } \\
\text { computer, laptop, projector, } \\
\text { cell phone. } \\
\text { Software related: Google } \\
\text { search engine, Gmail, } \\
\text { Facebook. }\end{array}$ & $\begin{array}{l}\text { It creates the joyful learning } \\
\text { environment and helps to know } \\
\text { the more information in short } \\
\text { period. } \\
\text { It helps them to compete in the } \\
\text { job market and funny learning } \\
\text { environment. }\end{array}$ \\
\hline My reflection & $\begin{array}{l}\text { Can immediately be used: } \\
\text { mobile/cell phone through } \\
\text { the internet facility for both } \\
\text { teachers and students. } \\
\text { Long-term use: e-library, } \\
\text { Moodle, electric whiteboard, } \\
\text { webinar, create forum etc. }\end{array}$ & $\begin{array}{l}\text { Help to create more collaborative } \\
\text { and cooperative learning. } \\
\text { Promote both the teachers and } \\
\text { learners more interactive and } \\
\text { communicative. } \\
\text { Promote the self-learning and } \\
\text { self-pace learning. }\end{array}$ \\
\hline
\end{tabular}

The table above made me clear that the most convenient tool was cell phone, which was preferred by both students and teachers. The male and female both used the internet facilities like Gmail, yahoo, Facebook, Skype and small documents type in his/her cell phone. They also preferred the Google search engine to search the new information and multimedia projector for material demonstration. 
My informants were found preferred the hardware tools like laptop/ desktop computer, multimedia projector, cell phone and software tools like internet, email, office program and related apps like Moodle. They emphasized the tools because they supported their lecture, demonstration, presentation in instructional situation and investigation for the new information. Likewise, it helped them to enable compete the global world. The students took it for the creation of joyful learning environment and easily assessable information and necessary for their job market. The tool which immediately was used cell phone in android version. It was the cheapest way to implementation. I also found that it facilitated to create more collaborative and cooperative learning. The e-library, Moodle, and electric whiteboard were also preferred for promoting the self-learning and self-paced leaning.

Lam and lawrence's (2002) finding useful who argued that the ICT not only help the learning process but also the access information. They also mentioned that the learning has not under the control of teachers. I also found such type of practice in the study area. The teaching learning procedures as I found was have been dominated by the teacher centric method and the students have believed on the teachers' authentication. But both teachers and students used the ICT tools for the access in information which had compelled both the groups to change their teaching and learning strategies. Similarly, Gulbahar and Guven (2008) emphasized the attitude of teachers for successful implementation. They further added that the teachers who have the computer in their home, he/she has the greater expertise than others. In the instructional context, teachers can use the collaborative projects with the help of ICT tools. In my research site, the teachers saw it for the creation of motivating and entertaining classroom. IT had facilitated the self-learning of teachers and students. The attitude of teachers was that ICT could improve the learning strategies and teachers' role through the supportive and collaborative way.

\section{Conclusion}

The effects of globalization have influenced to the teachers and students in their teaching and learning. At now, they both are trying to transform their roles into the ICT based activities in the classroom. They both teach and students have aware to use ICT tools in their pedagogy and trying to incorporate in their learning. The most convenience tools were computer, multimedia projector, cell phone, and internet for teachers and students. Both of them believed that ICT friendly leaning environment creates the more collaborative, supportive behavioral practices in classroom. ICT tools would be useful for the self-study and group work habits in learning. 


\section{Acknowledgements}

I am thankful to the teachers and students who provided the valuable information for this study. I am heartily embedded to Prof. Bidya Nath Koirala for inspirable guidance and productive comments during the study. I also remember to Prof. Lekha Nath Sharma and Ganesh Bahadur Singh for valuable comments and suggestions to improve my study report.

\section{References}

Aktaruzzaman, M., Shamim, M. R. \& Clement, C. K. (2011). Trends and issues to integrate ICT in teaching learning for the future world of education. International Journal of Engineering and Technology, 11(3), pp. 114-119.

Best, J. W. \& Kahn, J. V. (2006). Research in education. New Delhi: PHI learning Pvt. Ltd.

Creswell, J. W. (2007). Qualitative inquiry and research design: choosing among five approaches. New Delhi: Sage Publication.

Curriculum Development Center Nepal, (2007). National curriculum framework for school education in Nepal. Bhaktapur: Authors.

Ministry of Education Nepal, (2009). The school sector reform plan: 2009-2015. Kathmandu: Authors.

Ministry of Education Nepal, (2016). School sector development plan, Nepal, 20162023. Kathmandu: Authors.

Guba, E. G. \& Lincoln, Y. S. (2005). Competing paradigms in qualitative research. (N. K. Denzin \& Y. S. Lincoln, Ed. Handbook of qualitative research). California: Sage Publication.

Gulbahar, Y. \& Guven, I. (2008). A survey on ICT usage and the perceptions of social studies teachers in Turkey. Educational Technology \& Society, 11 (3), pp. 37-51.

Hennessy, S., Harrison, D., \& Wamakote, L. (2010). Teacher factors influencing classroom use of ICT in Sub-Saharan Africa. Itupale Online Journal of African Studies, 2, pp. 39- 54.

Lam, Y., \& Lawrence, G. (2002). Teacher-student role redefinition during a computerbased second language project: Are computers catalysts for empowering change? Computer Assisted Language Learning, 15 (3), pp. 295-315.

Luu, K.(2009). An analysis of the relationship between information and communication technology (ICT) and scientific literacy in Canada and Australia. Kingston, Ontario, Canada: Queen's University, Unpublished Thesis.

Mbangwana, M. A. (2008). Introduction of ICT in schools and classrooms in Cameroon. Bamendda. Cameroon: Langaa, Bamako. 
Ministry of Education Nepal, (2013). ICT in education master plan 2013-2017. Kathmandu: Authors.

Ndibalema, P. (2014). Teachers' attitudes towards the use of information communication technology (ICT) as a pedagogical tool in secondary schools in Tanzania: the case of Kondoa district. International Journal of Education and Research, 2 (2).

Olteanu, R. L., Dumitrescu, C., Gorghiu, G. \& Gorghiu,L. M. (2007). Pupils' perception concerning the implementation of ICT in the classroom. ICT in Education: Reflections and Perspectives. Bucharest, June 14-16.

Rhema, A., \& Miliszewska, I. (2014). Analysis of student attitudes towards e-learning: The case of engineering students in Libya. Issues in Informing Science and Information Technology, 11, pp. 169-190. http://iisit.org/Vo 111/IISITv11p169 190Rhema0471.pdf.

Ryba, K. (1992). Creating effective computer learning environments: People effects and social practices. In Kwork-Wing Lia and Bruce Macmillan (Eds.), Learning with Computers: Issues and Application in New Zealand. Palmerston North: The Dunmore Press.

Tech Target, (2007). Definition of information communication technology. Retrieved on August 10, 2007 from http://searchsmb.techtarget.com/sDefinition/0,,sid44_ gci928405,00.html

Treagust, D. F., \& Rennie, L. J. (1993). Implementing technology in the school curriculum: A case study involving six schools. Journal of Technology Education, 5(1), pp. 38-53.

UNESCO (2002). Information and communication technologies in teacher education: a planning guide. Paris: UNESCO Higher Education.

UNESCO (2014). Information and communication technologies (ICT) in education in Asia: a comparative analysis of ICT integration and e-readiness in schools across Asia. Canada: UNESCO Institute for Statistics.

Wiersma, W. \& Jurs, S. G. (2009). Research methods in education: an introduction. New Delhi: Dorling Kindersley Pvt. Ltd. 